\section{Marjorie Lansing}

Her academic career was relatively brief-from 1966 through 1986-but her contributions have lasting impact. Marjorie Lansing developed the "gender gap" concept and helped popularize the term with her path-breaking dissertation research that became the basis for Women and Politics: The Invisible Majority, published with Sandra Baxter in 1980. (When the book was revised and reissued, the subtitle read "The Visible Majority.") She died of cancer on May 1, 1998, at the age of 82 . Marjorie lived the life of scholaractivist in the best and noblest sense. In scholarship, she was intellectually honest. Although committed to the advancement of women in politics, she did not bend the data to fit her theories. In politics, she was forthright and energetic. And, she did not suffer fools, though she never resorted to the sort of personalized campaigning that has become the hallmark of contemporary politics.

Raised on a cattle ranch in Florida, Marjorie Tillis graduated from the (then) Florida State College for Women. After a brief stint teaching high school in Sanford, Florida, she traveled to Europe, an experience that heightened her activist bent and her interest in education. (One of several anecdotes about the trip: On the voyage to Europe, she would steal into first class to raise money for the Spanish loyalists from the passengers.) As war began, she returned to the states and entered Columbia to study for a master's degree in sociology, which she received within the year. Moving to Washington, DC, in 1940, she worked as a staff researcher for the Kilgore subcommittee to the Senate Judiciary Committee and as a field consultant for the National Federation of Business and Professional Women. In Washington she met John Lansing, and after the war they married and moved to Cambridge, Massachusetts, where he completed his doctorate in economics at Harvard. During these
Cambridge years, Marjorie plunged into liberal and leftist political causes and worked in the Henry Wallace campaign in 1948.

In 1949, the Lansing's moved to Ann Arbor, Michigan, where he joined the economics faculty at the University of Michigan. Marjorie raised three children and continued her political activism, becoming extensively involved in Democratic party politics. She chaired the Washtenaw County Democratic Party in 1960-61 and twice served as a delegate to the national convention (1960 and 1976). In 1974, she ran for U.S. House of Representatives, losing a hard-fought three-way primary. She also ran for the University of Michigan Board of Regents twice, in 1972 and 1984. Throughout her adult life, Marjorie Lansing supported the efforts of numerous other women candidates, both in Michigan and in other states. As her scholarly reputation coupled with her political activism translated into invited speeches, she dedicated her honoraria to women candidates, operating on the philosophy that there are never enough women candidates nor enough money for them.

Marjorie Lansing initiated her second, academic career in 1961, when she began her studies at the University of Michigan for the Ph.D. in political science. This mid-life career change put her in company of the early "retreads" or "recycled" women as she often described the career paths for wives and mothers of the 1950s and 1960s. She received the Ph.D. in 1970. Now a commonplace, in the early 1960s the idea that the political behavior of women might differ significantly from men was a difficult proposition to sell as a dissertation topic. Yet Marjorie was modest in a way about her work, remarking in a 1984 interview that she had been "lucky" to "catch the wave of the burgeoning interest in the women's movement."

In the midst of her doctoral work, Marjorie Lansing joined the faculty at Eastern Michigan University in nearby Ypsilanti, in 1966 as a lecturer, and in 1968 as a tenure-track faculty member. She retired as a full professor, emeritus, in 1986. During her tenure at EMU, Marjorie taught the University's first course in women's studies. She also was appointed department head in the crucial transition year of 1971-72, when the department became independent of an umbrella social sciences department and recruited its first external head. Notwithstanding her extensive political and scholarly activities, Marjorie Lansing put her family first-and put to the lie the too-frequent laments about the decline of "family values" when women undertake careers and social commitments. With the premature death of her husband in 1970, she saw her three children through their teen years, college, and their graduate studies as they developed their own scholar-activist careers (anthropologist, historian, and agricultural and community organizer).

The gender gap is the legacy most political scientists associate with Marjorie Lansing. To her colleagues at EMU she will be remembered for this, to be sure, and for being one of the department's leading scholars of the 1970 s and early 1980s. But we will remember her chiefly for her teaching and commitment to students and her collegial friendship. The New York Times eulogized her as "high-spirited" and "engaging," and that's right on target. Marjorie Lansing was the role model par excellence of teacher-scholar-activistany two of which are important for students' intellectual and professional growth and development; the three together are rare indeed. She was well known as an energetic and enthusiastic teacher who could bring to life the importance of participation and activism and link them with scholarship. On the occasion of her retirement in 1986, a former student and practicing attorney wrote: "Your example as a woman who gets involved and makes an impact has had, for me, a lasting effect. You 
truly have been a role model for me." For her students, their Professor Lansing had been there and done it in the trenches of political life- unlike our armchair philosophers and cafe intellectuals. She linked these experiences to the world of research, and she projected them with her boundless energy to make scholarship meaningful in ways that students understood and appreciated.

Robert C. Grady

David W. Hortin

Eastern Michigan University

\section{Myres Smith McDougal}

Myres Smith McDougal, Sterling

Professor Emeritus of Law at Yale University, died on May 7, after a long illness. He was 92 years old.

A renowned authority on international law, Professor McDougal founded, along with political scientist Harold D. Lasswell, the New Haven School of Jurisprudence, a policyscience approach to the study of law that conceives of law not as a body of rules, but as a process of decision.

Professor McDougal called his jurisprudence "configurative" and "policy-oriented." In his view, the challenge was to develop and apply an approach to the study and practice of law so that law could contribute to the achievement of a public order respectful of human dignity.

Aside from his prominence as a legal scholar, Professor McDougal, known as "Mac" to his students and colleagues, was a respected and popular teacher at the Law School for five decades, and after that, at the New York Law School. He nurtured generations of statesmen, judges, academics, and practicing lawyers.

President Bill Clinton, a 1973 graduate of Yale Law School and a former student of Professor McDougal, expressed sadness in a letter to the McDougal family and friends. Clinton wrote: "Mac was a central part of the Yale Law School community. His conception of the ultimate goal of law as the achievement of human dignity, and his insistence that each legal application be appraised in terms of its contribution to that dignity, inspired many of us to dedicate our lives to public service and will continue to guide our efforts."

Yale trustee Judge José A. Cabranes, another of Professor McDougal's former pupils, noted: "Mac's scholarship and his advocacy has touched most of the great foreign policy debates of our time: United States participation in the new, post-war order; the principles of law governing the exercise of coercive authority by great powers in that new order; the international protection of human rights (a subject that Mac helped to place on the map, and which he introduced to law school curricula); the use of executive agreements in the conduct of our foreign affairs; the application of international law by United States tribunals; the law of the sea; and the law of outer space (an interest of his that some of us in 1962 regarded, quite incorrectly, as eccentric).... Myres McDougal was, without a doubt, the greatest international lawyer of his time."

Professor McDougal was born in 1906 in Burton, Mississippi. He received a B.A., M.A. and LL.B. degrees from the University of Mississippi and was a Rhodes Scholar at Oxford, where he received a B.C.L. in 1930. At Oxford, he was a student of the legal historian Sir William Holdsworth, who had a profound influence on his later work. Although invited to teach at Oxford, Mr. McDougal returned to the United States to earn his doctorate in 1931 from the Yale Law School.

After a brief teaching stint at the University of Illinois, he returned to Yale in 1934. Working in the area of property law, he was the first scholar to reconceive this traditional body of law in terms of comprehensive resource planning.

During World War II, Professor McDougal took a leave from Yale to serve his country, first as assistant general counsel of the Lend-Lease Administration (1942); then as general counsel of the State Department's Office of Foreign Relief and Rehabilitation Operations (1943).

Professor McDougal turned his attention after the war to international law, and it was in this area that he made his best-known contributions. He produced, in collaboration with his students, six major treatises on international issues, including the law of the sea, the law of outer space, the law of war, and the law of human rights. In 1943, he and Lasswell published their first joint endeavor, "Legal Education and Public Policy," a fundamental and path-breaking work in its field.

Among his other positions, he served as president of the American Society of International Law in 1958, and was president of the Association of American Law Schools in 1966.

Professor McDougal is survived by his wife of more than 60 years, the former Frances Lee, and a son, John Lee McDougal.

Adapted from the Yale Bulletin \& Calendar

\section{Mancur Olson}

The sudden passing of Mancur Olson on February 19, 1998, at the age of 66 , was a blow to his many colleagues, admirers, and friends. Rarely, if ever, has one individual made such a notable difference to political science. His intellectual audacity was ever a trade mark of his style and always on display, as in the opening of his second volume, The Logic of Collective Action:

Since most (though by no means all) of the action taken by or on behalf of groups of individuals is taken through organizations, it will be helpful to consider organizations in a general or theoretical way.

This work, which identified the conflict between individual rational choice and the imperatives of action to support group goals, changed the way the world of political science thought of political behavior, political organizing, and the output of governments. (In 1993, the American Academy of Management awarded it a Best Book Award, for its enduring contributions to our understanding of society.) The contribution stemmed from Mancur's singular focus on the big questions of social science. He described this predilection nicely in a communication to Avinash Dixit in July 1997: 